\title{
Mechanism and block diagram model for seasonal variation of As in Jiaozhou Bay
}

\author{
Dongfang Yang 1, 2, 3, a , Qi Wang ${ }^{2}$, Haixia $\mathrm{Li}^{1,2}$, Longlei Zhang ${ }^{2}$, Jun Ding ${ }^{1,2}$ \\ ${ }^{1}$ Center for Accounting and Auditing Informatics, Xijing University, Xi'an 710123, China \\ ${ }^{2}$ Accountancy Shool, Xijing University, Xi’an 710123, China \\ ${ }^{3}$ North China Sea Environmental Monitoring Center, SOA, Qingdao 266033, China \\ adfyang_dfyang@126.com
}

Keywords: Arsenic (As); Seasonal variation; Mechanism; Block diagram model; Jiaozhou Bay.

\begin{abstract}
Using investigation on As in Jiaozhou Bay in April and July 1981, this paper researched the vertical distribution and seasonal variation of As contents, and defined the mechanisms. Results showed that As contents in surface and bottom waters were both in order of spring $>$ summer. The sedimentation of As from surface waters to bottom waters indicated the dilution effect and accumulation effect in water body. The seasonal variation of As contents in surface waters was determined by the changes of As input from river runoff and overland runoff, while in bottom waters was determined by the changes of water body's dilution effect and accumulation effect. In April and July 1981, the change ranges of As contents were closed. In case of As contents were low in surface waters, there was not significant dilution effect or accumulation effect in bottom waters. While in case of As contents were high in surface waters, there was accumulation effect in bottom waters. From temporal and spatial scales, and in April and July 1981, As contents in both surface and bottom waters were showing consistent trends of decreasing from the inner of the bay to the bay mouth, and to the open waters. The sedimentation of As determined the horizontal distributions of As contents in surface and bottom waters to be consistent. Furthermore, the mechanism of the seasonal variation of As was provided, as well as a block diagram model.
\end{abstract}

\section{Introduction}

As is widely used in agriculture, i.e., herbicide, pesticide, etc., and a great deal of As-containing wastes are generating and discharging along with the rapid development of agriculture [1-3]. As a result, many marine bays have been polluted by As via atmospheric deposition, river runoff discharge etc., and bottom waters in marine bay are also polluted by means of vertical water's effect [4-6].

Jiaozhou Bay is a semi-closed bay located in Shandong Province, China. Using investigation on As in Jiaozhou Bay in April and July 1981, this paper researched the vertical distribution and seasonal variation of As contents, and defined the mechanisms. The aim of this paper was to provide basis for research on the vertical sedimentation and horizontal migration of As in marine bays.

\section{Study area and data collection}

Jiaozhou Bay is located in the south of Shandong Province, eastern China $\left(35^{\circ} 55^{\prime}-36^{\circ} 18^{\prime} \mathrm{N}\right.$, $120^{\circ} 04^{\prime}-120^{\circ} 23^{\prime} \mathrm{E}$ ), with the total area and average water depth of $446 \mathrm{~km}^{2}$ and $7 \mathrm{~m}$, respectively. The bay mouth is very narrow (3 km) between Tuandao and Xuejiadao, and is connected to the Yellow Sea. There are a dozen of rivers, and the major rivers include Dagu River, Haibo Rriver, Licun Rriver, and Loushan Rriver etc.. All of which are seasonal rivers strongly impacted by seasonal factors [7-8].

The investigation on As in Jiaozhou Bay was carried on in April and August 1981 in 29 sampling sites (i.e., A1, A2, A3, A5, A6, A7, A8, B1, B2, B3, B4, B5, C1,C2, C3,C4, C5, C6, C7, 
C8, D1, D2, D3, D4, D5, D6, D7, D8 and D9) (Fig. 1). As in waters was sampled and monitored follow by National Specification for Marine Monitoring [9].

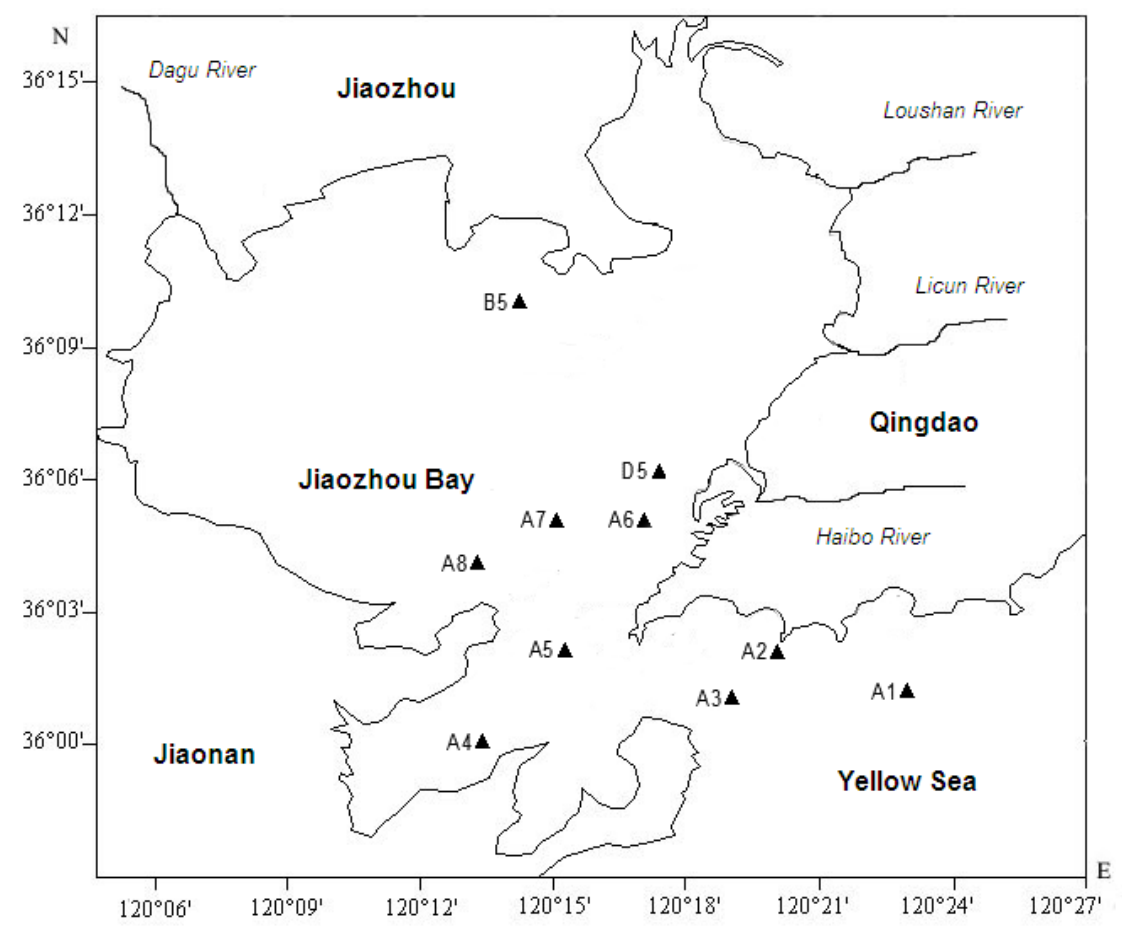

Fig. 1 Geographic location and sampling sites of Jiaozhou Bay

\section{Results}

\subsection{As contents in surface and bottom waters.}

In April 1988, As contents in surface waters and bottom waters were 1.04-1.88 $\mu \mathrm{g} \mathrm{L}^{-1}$ and 1.04-2.40 $\mu \mathrm{g} \mathrm{L}^{-1}$, respectively. In July 1988, Cd contents in surface waters and bottom waters were 1.00-1.80 $\mu \mathrm{g} \mathrm{L}^{-1}$ and 1.00-1.80 $\mu \mathrm{g} \mathrm{L}^{-1}$, respectively. In according to Sea Water Quality Standard (GB3097-1997), the As contents in both surface and bottom waters in April and August 1988 were confirmed to Grade I (20.00 $\left.\mathrm{g} \mathrm{L}^{-1}\right)$. The pollution level of As in Jiaozhou Bay in 1981 was still very slight.

Table 1 As contents and pollution levels in surface waters in Jiaozhou Bay 1988

\begin{tabular}{|c|c|c|c|c|}
\hline \multirow{2}{*}{$\begin{array}{c}\text { Month } \\
\text { Water layer }\end{array}$} & \multicolumn{2}{|c|}{ April } & \multicolumn{2}{|c|}{ July } \\
\hline & Surface & Bottom & Surface & Bottom \\
\hline $\begin{array}{l}\text { As content/ } \mu \mathrm{g} \\
\mathrm{L}^{-1}\end{array}$ & $1.04-1.88$ & $1.04-2.40$ & $1.00-1.80$ & $1.00-1.80$ \\
\hline Grade & I & I & I & I \\
\hline
\end{tabular}

\subsection{Seasonal variation of As contents in surface and bottom waters.}

April and August were spring and summer in study area. As contents in surface and bottom waters were both in order of spring $>$ summer (Table 1). It could be seen from Table 1 that As contents in surface waters in April 1981 was relative high, and in bottom waters was also relative high. Meanwhile, As contents in surface waters in August 1981 was relative low, and in bottom waters was also relative low. In general, As contents in bottom waters would be relative high/low in case of As contents in surface waters were relative high/low.

\subsection{Horizontal distributions of As contents in surface and bottom waters.}

In April 1981, As contents in surface waters were decreasing from the estuary of Haibo River (1.88 $\left.\mu \mathrm{g} \mathrm{L}^{-1}\right)$ to the bay mouth $\left(1.68 \mu \mathrm{g} \mathrm{L}^{-1}\right)$, and the open waters $\left(1.26 \mu \mathrm{g} \mathrm{L}^{-1}\right)$, while in bottom 
waters were also decreasing from the estuary of Haibo River $\left(2.40 \mu \mathrm{g} \mathrm{\textrm {L } ^ { - 1 }}\right)$ to the bay mouth $(1.40$ $\left.\mu \mathrm{g} \mathrm{L}^{-1}\right)$, and the open waters $\left(1.36 \mu \mathrm{g} \mathrm{L}^{-1}\right)$. In August 1981, As contents in surface waters were decreasing from the center of the bay $\left(1.42 \mu \mathrm{g} \mathrm{L}^{-1}\right)$ to the bay mouth $\left(1.32 \mu \mathrm{g} \mathrm{L}^{-1}\right)$, and the open waters $\left(1.12 \mu \mathrm{g} \mathrm{L}^{-1}\right)$, while in bottom waters were also decreasing from the center of the bay (1.80 $\left.\mu \mathrm{g} \mathrm{L}^{-1}\right)$ to the bay mouth $\left(1.44 \mu \mathrm{g} \mathrm{L}^{-1}\right)$, and the open waters $\left(1.10 \mu \mathrm{g} \mathrm{L}^{-1}\right)$. In general, the horizontal distributions of As in surface and bottom waters were consistent in each month.

\section{Discussion}

\subsection{Settlement of As.}

By means of vertical water's effect, As contents were changing while transporting through water body [4-6]. The growth and reproduction of marine organism are increasing from spring to summer, and at the same time a lot of colloids are generating that increasing the absorption capacity of suspending particular matters [8]. As a result, a big part of As are absorbed to the suspending particular matters and are transferring to sea bottom continuously by means of gravity force and marine current [1-6]. This continuous settlement process are exhibiting the vertical migration process of As.

\subsection{Seasonal variation of As.}

In surface waters in Jiaozhou Bay 198, As contents were decreasing from $1.88 \mu \mathrm{g} \mathrm{L}^{-1}$ in April to $1.80 \mu \mathrm{g} \mathrm{L}^{-1}$ in August. The major source of As in spring was river runoff and marine current whose source strength was relative strong, while the major source of As in summer was river runoff whose source strength was relative weak. Hence, As contents in surface waters were in order of spring > summer. By means of vertical water's effect and horizontal water's effect [4-6], there were dilution effect or accumulation effect in bottom waters along with the rapid and continuously sedimentation process. In case of As contents were low in surface waters, there was not significant dilution effect or accumulation effect in bottom waters. While in case of As contents were high in surface waters, there was accumulation effect in bottom waters. Hence, As contents were showing seasonal variations of As contents in bottom waters as spring > summer. As a whole, the seasonal variation of As contents in surface waters was determined by the changes of As input from river runoff and overland runoff, while in bottom waters was determined by the changes of water body's dilution effect and accumulation effect.

\subsection{Mechanism of the As's seasonal variation.}

Jiaozhou Bay is a semi-closed bay. At spatial scale, from coastal waters in the east, northeast and north of and bay and the estuaries of the major rivers to the bay mouth and then to the open waters, As contents in surface waters were showing decreasing trends. At temporal scale, As contents in surface and bottom waters were decreasing from spring to summer. These spatial-temporal variations demonstrated the rapid sedimentation process of As. The anthropogenic As wastes are discharging to soil water, and air, and are entering the water cycle finally. Hence, As would be transported to marine bays since ocean is the sink of pollutants, and would be fixed in sea bottom by means of vertical waters effect (Fig. 2). Once the rainy season has ended, most of the As was retained in soil surface and river bed, until the rainy season in the following year after six months. In spring season in the following year, the application of herbicide and pesticide in agricultural activities increase the emission of As to the environment (Fig. 2). Half a year later, the rainy season in the following year is coming. A lot of As was transported to the ocean by means of rainfall-runoff in the early rainy season, while in the late rainy season and the end of the year the load of As was decreasing since a big part of As had been transported to the ocean in the early rainy season. That was the mechanism of As's seasonal variation, as well as As's land migration process. 


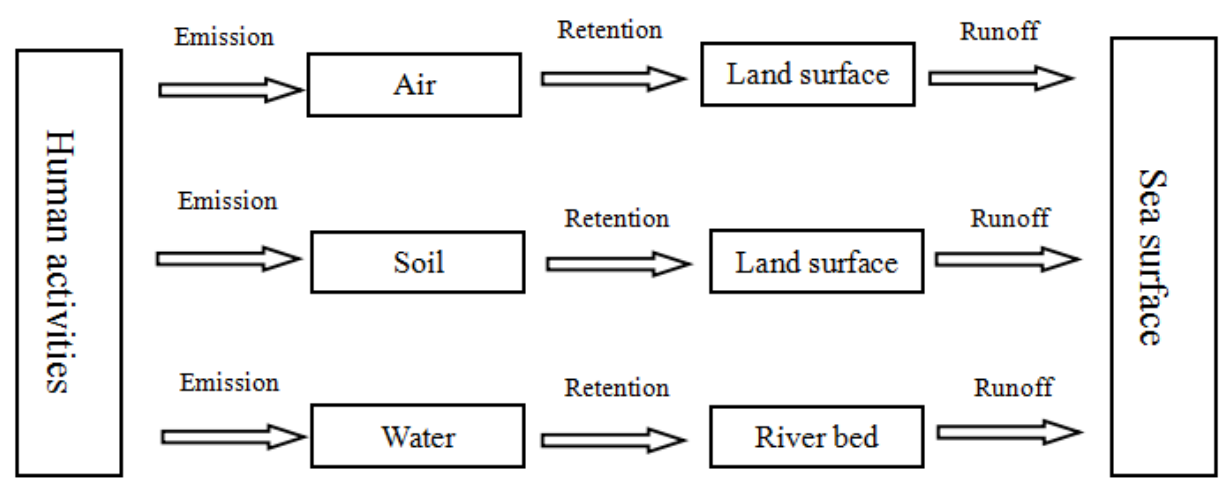

Fig. 2 Block diagram model for As’s land migration process in Jiaozhou Bay

\section{Conclusion}

As contents in surface and bottom waters were both in order of spring $>$ summer. As contents in bottom waters would be relative high/low in case of As contents in surface waters were relative high/low. In case of As contents were low in surface waters, there was not significant dilution effect or accumulation effect in bottom waters. While in case of As contents were high in surface waters, there was accumulation effect in bottom waters. The seasonal variation of As contents in surface waters was determined by the changes of As input from river runoff and overland runoff, while in bottom waters was determined by the changes of water body's dilution effect and accumulation effect.

\section{Acknowledgement}

This research was sponsored by Research Projects of Guizhou Nationalities University ([2014]02), Research Projects of Guizhou Province Ministry of Education (KY [2014] 266), Research Projects of Guizhou Province Ministry of Science and Technology (LH [2014] 7376).

\section{References}

[1] Yang DF, Song WP, Chen ST, et al.: Coastal Engineering, Vol.31 (2012), p. 47-55. (in Chinese)

[2] Yang DF, Zhao YH, Piao ZG, et al.: Ocean Development and Management, Vol. 31 (2014), p. 109-112. (in Chinese)

[3] Yang DF, Zhu SX, Wang FY, et al.: Meterological and Environmental Research, Vol. 5 (2014), p. 24-26.

[4] Yang DF, Wang FY, He HZ, et al.:Proceedings of the 2015 international symposium on computers and informatics, 2015, p. 2655-2660.

[5] Yang DF, Wang FY, Zhao XL, et al.:Sustainable Energy and Enviroment Protection, 2015, p. 191-195.

[6] Yang DF, Wang FY, Yang XQ, et al.: Advances in Computer Science Research, Vol. 3252 (2015), p. 198-204.

[7] Yang DF, Chen Y, Gao ZH, et al.: Chinese Journal of Oceanology and Limnology, Vol. 23(2005), p. 72-90. (in Chinese)

[8] Yang DF, Wang FY, Gao ZH, et al.: Marine Science, Vol. 28 (2004), p. 71-74. (in Chinese)

[9] China's State Oceanic Administration: The specification for marine monitoring (Ocean Press, Beijiang 1991). (in Chinese)

[10] Yang DF, Miao ZQ, Xu HZ, et al.: Marine Environmental Science, Vol. 32(2013), p. 373-380.(in Chinese) 